УДК 398-05 Цепенков,М.(049.3)

УДК $398(=163.3)(049.3)$

https://doi.org/10.55302/MF2180191p

Весна Петреска

\title{
ДРУГОСТА, РАЗЛИЧНОСТА, ОНОСТРАНОСТА ВО ТВОРЕШТВОТО НА МАРКО ЦЕПЕНКОВ
}

Книгата Otherworldly Tales Collected in 19th Century Macedonia by Marko Cepenkov во издание на Институтот за фолклор „Марко Цепенков“, 2021 година, под редакција на Фај Томев (Fay Tomev), д-p Ермис Лафазановски и дp Весна Петреска, е избор и превод на Фај Томев од десеттомното издание на најпознатиот македонски собирач Марко Цепенков Макеgонски нарояни

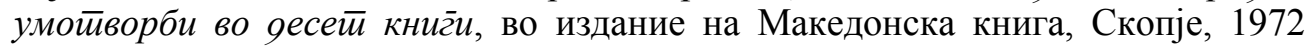
година. Како што самата Фај Томев истакнува, таа се приврзува со начинот на живот на нејзините предци во родниот крај и сака, на наследниците во дијаспората, на кои им припаѓа и таа - живее во Австралија, - преку преводот на англиски јазик, да им ги пренесе традиционалните начини на сфаќање на животот. Говорот во раскажувањата на нејзината баба Василка Машина (Vasilka Massina), родена Делоичина (Deloichina), која била родена во малото планинско село Лаген во Леринско во 1905 година, бил ист со оној на Марко Цепенков. Според усната историја, која ѝ била пренесена на Фај Томев, во ова село прво биле населени луѓе од Прилеп. Исто така, нејзините родители Доста Машина (Dosta Massina) и Коле Попов (Kole Popov), ѝ раскажувале многу за: начинот на живот, верувањата, обичаите и проблемите со кои се соочувале во текот на животот во нивниот роден крај. Нејзината мајка била многу вешта во раскажувањето за правењето и лечењето со помош на магии. Десеттомното издание на Цепенков (ова е нејзина втора книга, која е во издание на Институтот за фолклор „Марко Цепенков“, а првата е 19th Century Macedonian Folktales by Marko Cepenkov, во издание на Macquarie University Publications in Macedonian Literature, School of Modern Languages, NSW 2109. Printed by Clarendon Printing Pty Ltd. во 1991 г.), кое ѝ е блиско до раскажувањата на нејзината баба и на нејзините родители, е нејзина инспирација за да направи избор и превод на дел од ова издание.

Книгата Otherworldly Tales Collected in 19th Century Macedonia by Marko Cepenkov е поделена во два дела. Во првиот дел „Part 1- Beliefs, spells, the evil eye, healing remedies, scary stories, death rituals, lamentations and tall tales“, преведувачката прави избор и превод на дел од: верувањата, магиите, верувањата во лошите очи, народното лечење за кое во најголем дел биле задолжени жените. Овие се, обично, поместени во деветтата книга на Цепенков. Во првиот дел се застапени и неколку приказни (втора, трета, четврта, петта, седма книга) и поговорки и пословици (осма книга). Во овој дел се застапени и погребните обичаи (деветта книга) и тажачките, сврзани со нив, кои се поместени во првата книга од десеттомното издание на М. 
Цепенков. Кога се во прашање тажачките, може да се каже дека Марко Цепенков прв започнал да ги запишува и да ги претстави како непознат фолклорен жанр дотогаш (Саздов 1972, кн. 1: 15). Во слична насока и г-ѓа Фај Томев избира да преведе дел од нив, за кои може слободно да се каже дека не само во македонската средина, туку и во светски рамки, се во фаза на губење или пак се потполно изгубени. Карактеристично за тажачките, но и за другите собрани песни од М. Цепенков, е што сите песни, со мали исклучоци, имаат епска содржина, бидејќи и епиката, како раскажувачко-описна поезија, повеќе му одговара на Цепенков зашто тој, пред сѐ, е раскажувач (Пенушлиски 1972а, кн. 1: 333). Многу од тажачките му се запишани преку интерпретација од друг, како што вели самиот Цепенков, дека најчесто ги запишувал по кажување од неговата снаа (Саздов 1968: 145). Раскажувачката особеност на M. Цепенков ја гледаме и во: соништата, баењата, верувањата во натприродните суштества, на пример, верувањата за чумата, за сеништата, но и верувањата во судбината, т.е. во наречниците. Нив, тој вешто ги раскажал како приказни. Современите научни разбирања, ваквиот пристап, го вклучуваат во фолклористиката (Пенушлиски 1972б, кн. 9: 418).

Во вториот дел „Dream interpretations“, преведувачката прави избор на дел од соништата и на нивната интерпретација, кои се поместени исто така во деветтата книга кај Цепенков. Веродостојноста на интерпретираните соништа, Цепенков ја нагласува со кажување на имињата на оние што ги сонувале и „вистинитоста“ на сонот што ја доживеале сонувачите: „така беше станало“, „така излезе“, „ете тој сон како се изврши“ и сл. Темата во соништата и нивните толкувања кај Марко Цепенков се однесуваат на разновидни значајни проблеми од секојдневниот човеков живот, што е во согласност со антрополошките теории за влијанието на културата, за нејзиниот систем на културни модели преку кои можат да се разберат соништата, но, исто така и соништата влијаат на културата, обезбедувајќи искуства, што се потврдуваат, се модифицираат или ги шират културните модели на реалноста. Толкувањата на соништата Марко Цепенков ги забележал во кратка форма, додека соништата ги претставува во вид на приказни, во согласност со неговиот раскажувачки дух. Цепенков иако многу умешно ги дотерувал соништата, стилски и композициски, сепак, не се оддалечувал од народната традиција во поголема мера, која одлично ја познавал. Ако се анализираат собраните соништа и нивните толкувања од Цепенков од аспект на традиционалната култура, се забележува нивната магиска моќ. Ова е во согласност со сфаќањата дека познавањето на културата, односите меѓу луѓето во културата, овоможува подобро да се разберат соништата, нивната универзалност, нивните симболи и значења и нивната интерпретација. Накратко, соништата мораат да бидат разбрани во термини на културата, како што и културата може да биде разбрана во однос на сонот (Lohmann 2019: 327), односно значењето на сонот треба да се согледа од локалната култура. Толкувањето на соништата е во согласност со нивниот симболички јазик, кој ги следи културните норми во традиционалната култура.

Од десеттомното издание на Марко Цепенков Макеоонски нарояни

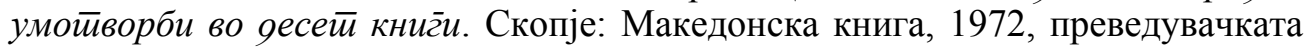


Фај Томев прави избор на собраните народни умотворби од М. Цепенков, коишто се однесуваат на оние што, на извесен начин, се поврзуваат со „оној или другиот“ свет, за оностраното, или пак за суштествата што не му припаѓаат на нашиот свет. Врската со „онаа страна“ може да се види преку определени просторни и временски категории, преку определени личности, животни или растенија, кои, во народната култура, се подразбираат дека конотираат со „другиот свет“. Избраните преведени народни умотворби се поместени во првата книга (во која се сместени песните собрани од Цепенков, од кои Томев ги зема тажачките), втората, третата, четвртата, петтата, седмата книга (во кои се застапени приказните), осмата (пословиците и поговорките, но изборот е направен само за оние што се во врска со болестите и со смртта) и деветтата книга во која се верувањата и соништата, но и баењата и обредните практики на бајачките.

Земајќи ги предвид основните човекови занимања во традиционалната култура - земјоделство, сточарство, а во градските средини - занаетчиството и трговијата, на луѓето им било многу важно годината да била родна, а семејството - во добро здравје. Настојувајќи да ги задоволи основните потреби - родна година, здравје за целото семејство, а не можејќ на друг начин да влијае поради екстензивното производство, луѓето се приклонувале и кон гатањата, претскажувањата. Во таа смисла се користеле коски од животни, многу често од кокошка, понекогаш црна; кукавица, јајце од штрк и речиси секогаш гатањето се вршело во определени пресвртливи временски периоди од народниот календар, на пример, околу Божиќ (со кој според народната година се преминува во следната), Велигден, но многу често и Ѓрѓ́овден (временски периоди со кои се преминува од ладниот во топлиот период од годината) итн. Најчестите основни мерила, според кои се определува симболичкиот статус на животните, е нивниот вертикален распоред според универзалниот симболички класификатор - дрвото на светот и хоризонталниот распоред според ритуалната вредност, заснована на различни оддалечености, која ја имаат одделни животни, во однос на човекот (Раденковић 1996: 85). Разгледувајќи го симболичкиот статус на кокошката и петелот, како во вертикалниот, така и во хоризонталниот распоред, се забележува дека тие имаат гранична или медијаторска улога, и затоа неслучајно се јавуваат во обредите на премин. Меѓу едни од карактеристиките на овие обреди е нивната придруженост со симболи на плодноста, но и со присуство на демонски карактеристики. Присуството на кокошката и на петелот во обредите на премин се сретнува како во оние од календарскиот циклус, така и во оние од социјалниот циклус (раѓање, свадба, смрт), но, исто така и во лекувачките магии и гатања. Кокошката и петелот како домашни животни носат и јаки социјални обележја, кои го обележуваат социјалниот простор, т.е. просторот населен со луѓе, за разлика од пустиот простор. Токму и дејствувањето на натприродните суштества престанува со пропејувањето на првите петли, болестите се праќаат на места каде што не се слуша петел, а пак токму нивни коски се јавуваат во гатањата и во претскажувањата за идната година и за здравјето на семејството, а ваквите гатања и претскажувања, Фај Томев ги дава во својот избор. 
Гатањата и претскажувањата се поместени во деветтата книга на М. Цепенков. Животинскиот код во врска со оностраното, може да се види и во верувањата во натприродните суштества што им се појавуваат на луѓето, коишто, Цепенков, вешто ги транспонирал во приказни. Во оваа смисла, натприродните суштества најчесто им се појавуваат на луѓето во вид на некои животни, најчесто: куче, мачка, јаре, кои се јавуваат на средината во однос на дрвото на светот, што значи дека имаат некоја медијаторска улога. Затоа, и не чуди што токму овие животни им се појавуваат на луѓето обично кога луѓето отстапуваат од пропишаните норми за однесување во заедницата (на пример, се движат во недозволено време и простор) бидејќи сепак тоа се едни пресвртливи моменти за луѓето што имале „средба со натприродните суштества“. Животните се, сепак, поблиску до природата или до онаа страна, за разлика од светот на човекот. Исто така и растенијата се јавуваат како медијатори, обично, во некои лекувачки магиски дејства или пак во магиските дејства на девојките и на момчињата за да ја здобијат нивната љубов, или пак на жените, да ја здобијат повторно љубовта на нивните мажи.

Оностраното, во поглед на определени личности, е особено забележливо кај бајачките, во баењата и во лекувачките обредни практики, кои, Фај Томев сосема оправдано ги избрала да бидат дел од преведените материјали. Во поглед на народните лекувачки или бајачки допирот со натприродното/оностраното го гледаме во старосниот принцип. Ова кај М. Цепенков убаво е илустрирано особено што бајачките најчесто ги ословува со баба: на пр., баба: Евда, Мара, Петра, Тема, Туна, Сава. Старосниот принцип е застапен и кај гатачите, претскажувачите на пр. на годината и успехот на семејството кога најчесто тоа биле луѓе во поодминати години, што значи дека имаат солидно животно искуство. Ова значи дека во најголем број случаи, бајачките се здобиваат со „моќта“ на лекувањето кога веќе ги исполниле репродуктивните способности и се завлезени во староста. Кога ќе се земе предвид дека и животот на човекот, во македонската традициска култура, а би рекла и во балканските култури, е структуриран, односно дека успехот на еден човек се состои од: основање семејство, одгледување потомство и нивно одомување, тогаш и фактот дека жената што престанала да раѓa, може да се третира дека таа ги исполнила условите определени од заедницата и е сѐ поблиску до нејзиниот физички конечен завршеток - со смртта, па оттаму и поблиску до другиот свет. Контактот на бајачките со оностраното/натприродното се гледа преку нивната комуникација со натприродни суштества, на пр., со самовили, а во христијанизирана форма, тие ги повикуваат на помош светиците, од кои најголема улога имаат Богородица, Света Петка и Света Недела, но и самиот Господ (Петреска 2008: 136; Петреска 2015: 157-162). Затоа и во баењата многу често се повикуваат на помош горенаведените светици и самиот Господ, а ова го гледаме и во некои баења кај Цепенков. Баењата се говорни формули со магиско значење. Кога ќе се земе фактот дека бајачките не ги кажуваат своите „вештини“ на други лица, или тоа го прават пред крајот на животот, но и тогаш на избрани поединци, тогаш со право се смета дека записите на Цепенков се мошне драгоцени (Пенушлиски 1972б, кн. 9: 420; Пенушлиски 1988, кн. 4: 357; 
Саздов 1986: 202). Со избраните преводи од Фај Томев, тие постануваат достапни и на поширокото јазично подрачје.

Предметите што ги користи бајачката се мошне разновидни, но, нивната функција соодветствува на закана и на истерување. Тука се различни растенија, различни метални остри предмети со кои може да се сече (нож, секира) и кои ја имаат извонредната моќ да ги пресечат и уништат нечистите сили. Тука е огнот и предметите во врска со него, итн. Самата тематика на баењата е вонредно интересна и разновидна, се бае за пород и лесно раѓање, да трае детето, против секакви болести и уроци, за среќна љубов и брак, за успеси во работата итн.

Врската на определени простори во врска со оностраното се изразува преку нивните карактеристики, кои обично се изразувале во опозициските двојки: свое/ туѓо; овој/ оној свет, блиску/ далеку итн. (Петреска 2008: 76). Во овој ред може да се споменат: водата, раскрсници, огниште, двор, воденици, кои и во собраните народни умотворби кај М. Цепенков особено се застапени во баењата, соништата, во приказните при средбата со натприродни суштества. Во многу од нив Цепенков прави и опис на изгледот на натприродните суштества.

Определени простори се особено застапени при магиските обреди при почнување нова работа, на пример, заплетување, особено кај девојчињата, кои на овој начин се воведувале во нов социјален статус. Првата работа најчесто се фрлала во вода или во оган со изговарање на определени магиски формули. Во слична насока се и временските категории кога, на пр., средбата со натприродните суштества најчесто се случува во временски периоди, кои не се определени за луѓето. Секогаш средбата се случува во ниедно време на ноќта, т.н. глуво доба, што асоцира на структурирање на социјалното време, односно дека ноќта е време за одмор. Бајачките најчесто нивните баења ги вршат во текот на ноќта за да се истера болеста или пред изгревот на сонцето, што значи дека „новиот живот“ за болниот треба да почне со доаѓањето на денот. Љубовните магиски дејства се вршеле, обично, спроти некој голем празник, на пр.: Божиќ, Велигден, кои и се врзуваат за премините од една годишна сезона во друга.

За врската со оностраното во соништата не ни треба посебно да се нагласува ако се земе фактот дека и во народната култура сонот се сметал како посебна состојба. Многу често, на луѓето, во сонот, им се претскажувале некои идни настани. При тоа особено повторно се значајни определени простори или предмети, како и определени личности - блиски роднини, стари луѓe, но, и овде повторно се појавуваат некои светци, како и самиот Господ. Во поглед на просторот и на предметите, можат да се споменат: водата, определени калливи површини, сопствениот или туѓ двор, определени патишта, дрва, заб, пушка, пиштол или само истрели, бастун итн. Средбата со починати сродници обично асоцира на некоја несреќа или смрт, но, понекогаш „тие“ им го кажуваат начинот на излегување, од кризна состојба, на нивните живи роднини. Птиците, на пр.: гулаб, ластовица, како и животните, на пр.: змија, гуштер, мечка, свиња, мачка, исто така се сретнуваат во соништата и според народниот светоглед може да подразбира добра или лоша судбина. 
Тематиката на соништата (заедно со толкувањата) е вонредно занимлива и зафаќа многубројни и разновидни контрастни важни проблеми од секојдневниот човечки живот. Најчестите мотиви се: одомувањето на сопствените деца, добивањето дете, односно забременувањето, успешната или неуспешната работа, здравјето, болеста како и смртта. Во соништата, особено при лекување или да бидат здрави децата, на луѓето им се прикажува одењето на определени простори и вршење на определени обреди, кои, во реалноста, ги практикувале. Во овој контекст можат да се споменат соништата во кои, на луѓето, им се прикажувале начините за нивно лечење - одење кај некои води во близина на некоја црква, или само преноќевање во цркви, манастири; преноќевање на вода во црква со која се миел болниот итн. Исто така, интересен мотив што го наведува М. Цепенков, во соништата, е „траењето на децата“" (сон бр. 227. Да сонуваш како да ти траат децата). Всушност, во реалниот живот кога на млади брачни парови им умирале децата, прибегнувале кон различни обредни практики, на пр.: промена на кум со оставање на детето на пат, на раскрсница и оној што ке се сретне, да биде кум, обред познат како „најден“, „сретен“ кум. Но, во наведениот случај, односно во сонот, станува збор за непочитување на „старото кумство“, односно кумот е сменет без негова согласност (според народните верувања за промена на кум без негова согласност, следуваат едни од најтешките казни пропишани од заедницата, во многу случаи немање пород или неможност родените деца да останат во живот) и за да остане детето во живот, за крштевањето на ова дете треба да се бара стариот кум.

Погребните обичаи и тажачките самите по себе се во врска со другиот свет, бидејќи човекот го завршува својот живот. Она што е карактеристично за тажачките, кај кои покрај што веќе е истакнато дека е застапена епска содржина, во нив обично е опишан животот на починатата личност, како и болеста со која се соочила и била причина за смртта. Тажачките најчесто ги кажувале жените, а многу често и во моментот кога доаѓале роднините или пријателите да се простат со починатиот, жените се надоврзувале една на друга во тажењето. Надоврзувањето на жените во тажењето е уште една потврда дека смртта е социјален чин.

Кратките фолклорни жанрови претставуваат непроценливо богатство за македонската фолклористика, за кои, Марко Цепенков, покажувал голема заинтересираност. Во нив е одразена големата мудрост на нашиот народ, а преку нив е одразен и речиси целокупниот живот на Македонецот во изминатите векови, па затоа можат да послужат и за запознавање со животот на Македонците во минатото. Од поговорките и од пословиците, како што истакнавме погоре, Фај Томев прави избор на оние што се во врска со болестите и смртта, што повторно се доведува во врска со „онаа страна“.

Она што го карактеризира собирачкото дело на Марко Цепенков е неговиот извонреден илустративен материјал за народниот живот, со што дава вистинска слика на општествено-патријархалните и на морално-етичките норми што ги фиксирало времето во разните свои периоди. Ова се гледа преку: неговите описи на народните обичаи и верувања, толкувањата на соништата, поговорките и пословиците, како и во народните приказни. Во 
изборот на Фај Томев за превод на народните приказни се земени, главно, предвид оние што се во врска со натприродните суштества-сеништа, кои им се појавуваат на оние личности што се движат во недозволено време; навите, кои ги „напаѓаат“ родилките; наречниците, кои им се појавуваат на родилките на третата вечер и ја определуваат судбината.

Изборот што го прави Фај Томев од творештвото на Марко Цепенков е збогатен и со визуелен приказ, преку фотографиите на Јозеф Обрембски, кои ce наоѓаат во Special Collections \& University Archives, University of Massachusetts Amherst Libraries, United States of America, (MS599). Jозеф Обрембски - познат полски етнолог и социолог, е еден од најзначајните странски истражувачи на народната култура на Македонците, кој собрал богат теренски етнографски и фолклорен материјал од непроценлива вредност и е автор на голем број трудови со македонска тематика (Обрембски 2003: 5). Најголем дел од резултатите на неговите македонски теренски истражувања (теренските белешки се водени на: полски, македонски и англиски јазик), се обработени во периодот на неговиот живот и се сместени, исто така, во неговата архивска оставина, депонирана во Special Collections \& University Archives, University of Massachusetts Amherst Libraries, United States of America. Објавени се постхумно во македонски превод во тритомната едиција подготвена од Т. Вражиновски (2001-2002, кн. 1-3), со исклучок на две статии за македонската магија и религија публикувани во 30-тите години во еден од полските културни весници (Halpern 2003: 64).

Творештвото на Цепенков е многу значајно за македонската култура. Тоа го привлекува вниманието на научната мисла и во пошироки размери кога cѐ повеќе и сѐ почесто се објавува и се преведува и на странски јазици (Пенушлиски 1988, кн. 4: 283). Во оваа смисла, преводот на дел од собраните народни умотворби од Фај Томев е од исклучително значење за запознавање со традиционалната македонска култура во пошироки светски рамки. Ова е засилено со фактот што самата Ф. Томев, иако родена во Австралија, сепак добро ја познава традиционалната македонска култура преку раскажувањата на нејзината баба и на нејзините родители, кои очигледно биле нејзини љубители. Нејзиното познавање на традиционалната македонска култура е дополнителен услов при преводот добро да се пренесе изворниот материјал.

\section{ЛИТЕРАТУРА}

\section{Кирилични изданија}

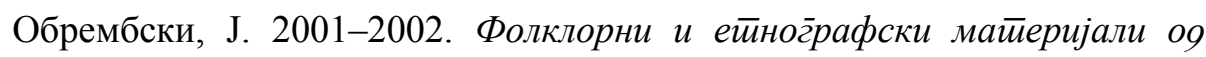
Порече, кн. I. Ред. Танас Вражиновски, Институт за старословенска култура Матица Македонска, Скопје-Прилеп, 2001; Макеоонски еш̄носоичолошки $c \bar{u} y q u и$, кн. II. Институт за старословенска култура - Прилеп, Матица Македонска - Скопје, Скопје-Прилеп, 2001; Макеgонски ейносочиолошки $c \bar{u} y q u и$, кн. III. Институт за старословенска култура - Матица Македонска Скопје, Скопје-Прилеп, 2002.

Обрембски, Ј. 2003. Порече 1932-1933. Главен и одговорен уредник Танас Вражиновски. Уредници: Ана Енгелкинг, Џоел. М. Халперн. Институт 
за старословенска култура - Прилеп, Институт за етнологија и културна антропологија на Универзитетот во Варшава. Прилеп-Скопје: Институт за старословенска култура - Матица Македонска.

Пенушлиски, К. 1972а. „Поговор“. Кон: Марко К. Цепенков.

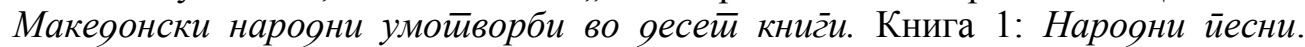
Скопје: Македонска книга, стр. 331-333.

Пенушлиски, К. 1972б. „Кон етнографските материјали на Марко К.

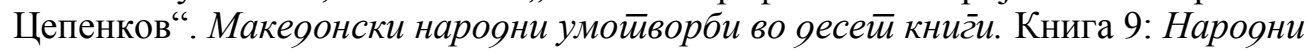
верувања. Дейски иг̄ри. (Ред. Кирил Пенушлиски и Лепосава Спировска). Скопје: Македонска книга, стр. 415-421.

Пенушлиски, К. 1988. Оябрани фолклористиички йруяови, кн. 4. Скопје: Македонска книга.

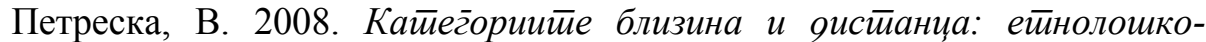

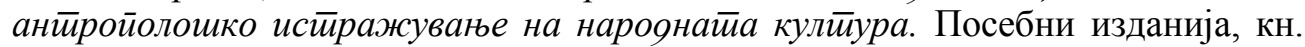
72. Скопје: Институт за фолклор „Марко Цепенков“.

Петреска, В. 2015. „Сродување со другиот/ блискиот: етнолошкофолклористичко истражување во балкански рамки на примери на сродување со натприродното“. Прилози од Меѓународниот симпозиум одржан на 19. - 20

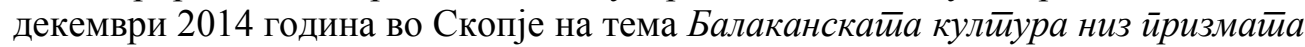

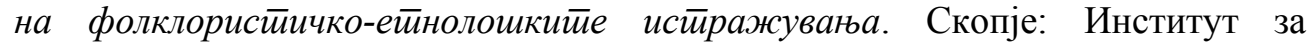
фолклор „Марко Цепенков“.

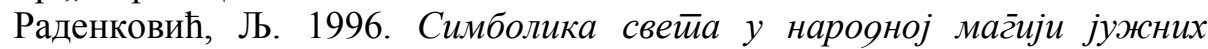
Словена. Посебна издања књ. 67. Ниш-Београд: Просвета-Балканолошки институт САНУ: Наша книга.

Саздов, Т. 1968. Марко К. Цейенков како собирач на макеоонски нарояни умойворби. Скопје: Универзитет „Св. Кирил и Методиј“, Филолошки факултет „Блаже Конески“. [Докторска дисертација].

Саздов, Т. 1972. „Марко К. Цепенков (1829-1920)“. Макеоонски нарояни

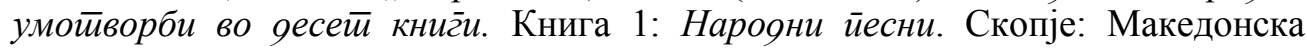
книга.

Саздов, Т. 1986. Фолклористиички стиуячи. Скопје: Наша книга.

Цепенков, К. М. 1972. Макеоонски нарояни умойворби во яесей книгии. Пенушлиски К., Б. Ристовски и Т. Саздов (ред.). Скопје: Македонска книга.

\section{Латинични изданија}

Halpern, J. 2003. "The Macedonian village photographs of Jozef Obrembski in the early 1930s - a perspective from his writings". Jozef Obrembski. Macedonian Poreche 1932-1933. Editor-in-chief: Tanas Vražinovski. Editors: A. Engelking \& J. M. Halpern. Institute for old Slavonic culture - Prilep, Institute of ethnology and cultural anthropology, University of Warsaw. Institute for old Slavonic culture Matica Makedonska: Prilep-Skopje, 63-92.

Lohmann, I. R. 2019. Culture and Dreams. In: Kenneth D. K. (ed.) CrossCultural Psychology: Contemporary Themes and Perspectives, (327-341). Second Edition. Published in 2019 by John Wiley \& Sons Ltd. Chapter - March 2019. https://DOI: 10.1002/9781119519348.ch15 
Thomev, F. 1991. 19th Century Macedonian Folktales by Marko Cepenkov. Macquarie University Publications in Macedonian Literature. School of Modem Languages, NSW 2109. Printed by Clarendon Printing Pty Ltd.

Thomev, F. 2021. Otherworldly Tales Collected in 19th Century Macedonia by Marko Cepenkov. Selected and translated by Fay Thomev. Skopje: Institute of folklore "Marko Cepenkov". 